\title{
Toxigenic properties and stx phage characterization of Escherichia coli 0157 isolated from animal sources in a developing country setting
}

Mahdia Rahman ${ }^{1}$, Ashikun Nabi ${ }^{1,2}$, Md Asadulghani ${ }^{1}$, Shah M. Faruque ${ }^{1,3}$ and Mohammad Aminul Islam ${ }^{1 *}$ (D)

\begin{abstract}
Background: In many Asian countries including Bangladesh E. coli $\mathrm{O} 157$ are prevalent in animal reservoirs and in the food chain, but the incidence of human infection due to $E$. coli $\mathrm{O} 157$ is rare. One of the reasons could be inability of the organism from animal origin to produce sufficient amount of Shiga toxin (Stx), which is the main virulence factor associated with the severe sequelae of infection. This study aimed to fill out this knowledge gap by investigating the toxigenic properties and characteristics of stx phage of E. coli O157 isolated from animal sources in Bangladesh.

Results: We analysed $47 s t x_{2}$ positive E. coli 0157 of food/animal origin for $s t x_{2}$ gene variants, Shiga toxin production, presence of other virulence genes, stx phage insertion sites, presence of genes associated with functionality of stx phages $\left(Q_{933}\right.$ and $\left.Q_{21}\right)$ and $s t x_{2}$ upstream region. Of the 47 isolates, 46 were positive for both $s t x_{2 a}$ and $s t x_{2 d}$ while the remaining isolate was positive for st $x_{2 d}$ only. Reverse Passive Latex Agglutination assay (RPLA) showed that 42/47 isolates produced little or no toxin, while 5 isolates produced a high titre of toxin (64 to 128). 39/47 isolates were positive for the Toxin Non-Producing (TNP) specific regions in the stx 2 promoter. Additionally, all isolates were negative for antiterminator $Q_{933}$ while a majority of isolates were positive for $Q_{21}$ gene suggesting the presence of defective stx phage. Of the yehV and wrbA phage insertion sites, yehV was found occupied in 11 isolates while wrbA site was intact in all the isolates. None of the isolates was positive for the virulence gene, $c d t$ but all were positive for hlyA, katP, etpD and eae genes. Isolates that produced high titre Stx $(n=5)$ produced complete phage particles capable of infecting multiple bacterial hosts. One of these phages was shown to produce stable lysogens in host strains rendering the Stx2 producing ability.
\end{abstract}

Conclusion: Despite low frequency in the tested isolates, E. coli O157 isolates in Bangladesh carry inducible stx phages and have the capacity to produce Stx2, indicating a potential risk of E. coli O157 infection in humans.

Keywords: E. coli O157, Shiga toxin 2, Toxin non-producing, stx phage

\footnotetext{
* Correspondence: maislam@icddrb.org

${ }^{1}$ Enteric and Food Microbiology Laboratory, Laboratory Sciences and Services

Division (LSSD), International Centre for Diarrhoeal Disease Research,

Bangladesh (icddr,b), Mohakhali, Dhaka 1212, Bangladesh

Full list of author information is available at the end of the article
}

(c) The Author(s). 2018 Open Access This article is distributed under the terms of the Creative Commons Attribution 4.0 International License (http://creativecommons.org/licenses/by/4.0/), which permits unrestricted use, distribution, and reproduction in any medium, provided you give appropriate credit to the original author(s) and the source, provide a link to the Creative Commons license, and indicate if changes were made. The Creative Commons Public Domain Dedication waiver (http://creativecommons.org/publicdomain/zero/1.0/) applies to the data made available in this article, unless otherwise stated. 


\section{Background}

Gastrointestinal infection caused by virulent Escherichia coli $\mathrm{O} 157$ in humans can lead to haemorrhagic colitis and often to a more serious complication, known as haemolytic-uremic syndrome. Cattle are asymptomatic reservoirs for E. coli O157 [1-3]. Food products contaminated by cattle feces (either direct or indirect contamination) are the cause of numerous outbreaks $[2,4,5]$.

Shiga toxins (Stx1 and Stx2) are the important virulence factors of E. coli $\mathrm{O} 157$ that play a crucial role in the progression of the most severe form of the disease in human. Epidemiological data suggest that Stx2-producing E. coli O157 isolates are more commonly associated with serious diseases than isolates producing Stx1 [6]. stx phages are temperate lambdoid bacteriophages and Shiga toxin genes are located in the late-phase region, downstream of $Q$ homologue and upstream of genes $S, R$ and $R z$, required for the release of phage particles [7]. Furthermore, st $x$ phages are heterogeneous in nature since they differ in their DNA structures, PFGE pattern, virion morphology and spectra of hosts [8]. DNA damaging agent such as UV-light and certain antibiotics that effect DNA synthesis, such as mitomycin $\mathrm{C}$ and trimethoprim-sulfamethoxazole, can provoke the induction of phages [9]. Induction of lysogenized phages eventually leads to the lysis of host bacterial cell and deliverance of free infectious phage particles [10]. These free phage particles play an important role in the transduction of stx genes to susceptible bacteria and thus can lead to the emergence of new Shiga toxin-producing $E$. coli (STEC) pathogens by horizontal gene transfer [11].

Although E. coli $\mathrm{O} 157$ is frequently isolated from cattle, with a prevalence varying from 0 to $41.5 \%[1,12]$, the human infections are relatively uncommon despite the low infectious dose of the organisms [13, 14]. In Bangladesh, there is a high prevalence of E. coli O157 in slaughtered animals especially in buffalo and cow [15]. Raw meats from these animals were also found contaminated with E. coli O157 [16]. Although diarrheal stool samples are not routinely tested for E. coli $\mathrm{O} 157$ in Bangladesh, several studies have indicated a very low prevalence of this organism among patients with diarrhea [17]. Several studies reported the similar trend of data in other Asian countries including Thailand and Malaysia [18, 19].

A previous study has shown that E. coli O157 isolates from bovine and human origin are distributed among two separate genetic lineages and the isolates of bovine lineage are less virulent or not capable of transmitting to humans [20]. In general, bovine originated O157 isolates produce a low amount of Shiga toxins as compared to virulent strains isolated from human [21, 22]. In Asian countries, one common reason for the low or no toxin production capacity of bovine $E$. coli $\mathrm{O} 157$ isolates is linked to the presence of genetically defective stx phages. Previous study has demonstrated that the defective phages carry mutations in the promoter region of the $s t x_{2}$ gene [23]. The defective promoter region and the absence of bacteriophage antiterminator gene $Q_{933}$ in the integrated phage genome inhibit the expression of stx 2 genes in these strains. The product of $Q_{933}$ gene acts at qut ( $\mathrm{Q}$ utilization sequence) and promotes the transcription of terminators, $t_{R}$, that activates the phage late promoter $p_{R^{3}}$ which is essential for strong stx $x_{2}$ transcription and is associated with higher Shiga toxin production [23]. In $s t x_{2}$ phage genome, the stx $x_{2}$ gene is located downstream of $Q$ gene. To identify the defective upstream regions of $s t x_{2}$ gene expanding from $q$ to $s t x_{2}$, PCR primers were designed from $Q$ gene and its flanking region and these PCR assays have been used as diagnostic tools for identification of toxin-non-producing (TNP) strains of E. coli $\mathrm{O} 157$ [12, 23]. A similar PCR assay named as NM-PCR has been developed by Taylor et al. for detection of the region from $Q$ to $s t x_{2}$ gene [24].

We hypothesize that $E$. coli O157 strains from animal origin in Bangladesh are less virulent to cause infection in humans, however the potential for enhanced pathogenicity and evolution of STEC strains cannot be ruled out, given that predicted climate changes associated with adverse natural events in this region. In this study, we analysed a collection of $E$. coli O157 strains isolated from slaughtered animals and raw meats in Bangladesh for their ability to produce Shiga toxin. E. coli O157 isolates with varying range of toxigenicity were further analysed for induction and propagation of the lysogenic stx phage, as well as the genetic diversity of the phages.

\section{Methods}

\section{Bacterial strains}

A total of $47 \mathrm{E}$. coli $\mathrm{O} 157$ isolates were included in this study. Of these 40 were isolated from fecal samples from 174 buffalo, 139 cows, and 110 goats at a slaughterhouse in Dhaka of the Mohakhali area in Bangladesh during the period from January to May 2006. The remaining 7 samples were isolated from 90 raw meat samples from the same slaughterhouse during the period from July 2006 to January 2007. Previous studies described details about isolation methods and sources of these strains $[15,16]$.

\section{Assays for toxin production by $E$. coli 0157 isolates}

Stx2 production was tested using a commercially available reverse passive latex agglutination kit (Oxoid VTEC-RPLA Toxin Detection Kit, Remel, Lenexa, KS, USA) according to the manufacturer's instruction. Briefly, isolates were grown at $37{ }^{\circ} \mathrm{C}$ overnight on brain-heart infusion agar from which a few isolated colonies were taken to make a suspension in normal saline supplemented with polymixin B $(5000 \mathrm{U} / \mathrm{ml})$. The suspension was incubated for $30 \mathrm{~min}$ 
followed by centrifugation at $4000 \mathrm{rpm}$ for $20 \mathrm{~min}$. Supernatant was transferred to a 96-well V-bottom microtitre plate and two- fold serial dilutions were made with a supplied diluent. Stx2 was detected by adding test reagents to each of the wells and the plate was incubated at room temperature for $24 \mathrm{~h}$. Visual appearance of agglutination indicated positive result. RPLA titre was defined by the reciprocal of the highest dilution of test sample giving a positive agglutination. E. coli $\mathrm{O} 157: \mathrm{H} 7 \mathrm{NCTC} 12079$ and $E$. coli O157:H7 NCTC 12900 was used as positive and negative control, respectively. The sensitivity of the test is 1 to $2 \mathrm{ng} / \mathrm{ml}$ of $E$. coli Shiga toxin.

\section{Detection of virulence genes by PCR}

Isolates were tested for the presence of virulence gene $\left(s t x_{1}, s t x_{2}, e a e, h l y_{E H E C}, k a t P\right.$, and $e t p D$ gene) by PCR following methods described earlier [16]. Isolates carrying $s t x_{2}$ genes were subtyped by PCR following the procedure described by Scheutz et al. [25]. Presence of cytolethal distending toxin $(c d t)$ gene was detected by PCR following conditions as described [26].

\section{Identification of TNP strains by PCR assays}

All isolates were tested by three different PCR assays such as TNP-PCR, NM-PCR and PCR for antiterminator gene alleles. DNA was extracted from bacterial cells by boiling a single colony in distilled water. In TNP-PCR assay, four separate PCR reactions (TNP-A, TNP-B, TNP-C and TNP-D) were carried out with seven primers described by Koitabashi et al. [23]. An isolate was considered TNP-PCR positive if expected amplicons were observed in all four reactions. For NM-PCR, $0.5 \mu \mathrm{M}$ of each forward and reverse primer, NM-F and NM-R was added to mastermix [24]. Bacteriophage antiterminator gene alleles $Q_{933}$, and $Q_{21}$ were detected by PCR as described previously [12]. E. coli O157:H7 NCTC 12079 was used as positive control for detection of $Q_{933}$ gene.

\section{Determination of $s t x_{2}$ phage integration sites in the $E$. coli genome}

The $s t x_{2}$ phage integration sites in E. coli $\mathrm{O} 157$ isolates were determined by PCR for wrbA and yeh $V$ gene loci and genes present in their left and right junctions following the methods described by Shaikh and Tarr [27]. Amplification of genes indicates that the insertion locus is intact and no phage is inserted while no amplification may indicate that $s t x_{2}$ phage is inserted and thus the site is occupied. Occupancy of a site was confirmed by detecting regions flanking the left and right junction of the phage.

\section{Bacteriophage induction, isolation and preparation of phage lysate}

The lytic cycle of temperate bacteriophages was induced by mitomycin $\mathrm{C}(\mathrm{MMC})$ treatment as described earlier
$[10,28]$. Briefly, a single colony of each isolate from MacConkey agar plate was inoculated into $6 \mathrm{ml}$ of LB broth supplemented with $5 \mathrm{mM} \mathrm{CaCl}_{2}$ and incubated at $37{ }^{\circ} \mathrm{C}$ for $18-24 \mathrm{~h}$ with shaking. The culture was adjusted to 0.1 at $600 \mathrm{~nm}$ optical density (OD) with the addition of fresh LB broth and incubated at $37{ }^{\circ} \mathrm{C}$ with shaking until the OD of culture reached 0.2-0.4. After incubation, culture was divided into two equal aliquots and $\mathrm{MMC}$ was added to one portion at a final concentration of $1.0 \mu \mathrm{g} / \mathrm{ml}$. Both aliquots of culture were then incubated at $37{ }^{\circ} \mathrm{C}$ with shaking $(120 \mathrm{rpm})$. Bacterial growth in two aliquots was monitored by taking OD values at $1 \mathrm{~h}$ interval consecutively for $10 \mathrm{~h}$ and phage-mediated lysis of cells was revealed by a decreasing trend of OD value at $600 \mathrm{~nm}$. The entire process of phage induction and phage-mediated lysis of bacterial cells was repeated three times for each isolate [10]. OD values obtained from all three replicas of each isolates were analysed for mean and standard deviation, which were plotted against time to depict the kinetics of phage induction.

\section{Extraction of $s t x_{2}$ phage DNA}

To confirm the presence of $s t x_{2}$ gene in phage DNA, phage DNA from the isolates was isolated from $100 \mathrm{ml}$ of cultures following the procedure described earlier [28]. Briefly, bacterial isolates were grown in LB broth supplemented with MMC $(1 \mu \mathrm{g} / \mathrm{ml})$ for $10 \mathrm{~h}$. Culture broth was centrifuged and supernatant was collected and filtered through low protein-binding $0.22 \mu \mathrm{m}$ membrane filters. Filtered supernatant was treated with polyethylene glycol (PEG) (20\%) supplemented with 10\% $\mathrm{NaCl}$ and kept at $4{ }^{\circ} \mathrm{C}$ for overnight. Treated supernatant was centrifuged and the pellet was re-suspended in SM buffer $\left[0.58 \% \mathrm{NaCl}, 0.2 \% \mathrm{MgSO}_{4} .7 \mathrm{H}_{2} \mathrm{O}, 1 \mathrm{M}\right.$ Tris-Cl (pH 7.5), $0.01 \%$ gelatin]. The suspension was treated with DNase $1(10 \mathrm{mg} / \mathrm{ml})$ and RNase $(10 \mathrm{mg} / \mathrm{ml})$ followed by proteinase $\mathrm{K}(20 \mathrm{mg} / \mathrm{ml})$. DNA was extracted using equal volume of Phenol: Chloroform: Isoamyl alcohol (25:24:1) followed by precipitation with double volume of absolute alcohol and $3 \mathrm{M}$ sodium acetate ( $\mathrm{pH}$ 4.6). Phage DNA was dissolved in TE buffer and stored at $-20{ }^{\circ} \mathrm{C}$ until further use. stx $x_{2}$ gene was detected in phage DNA by PCR as described previously [16].

\section{Determination of genetic diversity of $s t x_{2}$ phages}

To determine genetic diversity of the phages, DNA was subjected to Field Inversion Gel Electrophoresis (FIGE) analysis as described earlier [28]. Briefly, precipitated phage particles were dissolved in TES buffer $(10 \mathrm{mM}$ Tris-Cl, $10 \mathrm{mM} \mathrm{MgCl} 2,100 \mathrm{mM} \mathrm{NaCl}$ ) which was embedded in plugs of $1 \%$ Certified Low Melt Agarose (Bio-Rad Laboratories, Inc., CA, USA). Plugs were treated with DNase I $(1000 \mathrm{U} / \mathrm{ml})$, RNase A $(50 \mu \mathrm{g} / \mathrm{ml})$ 
in DNase I buffer (10 mM Tris pH 7.5, $2 \mathrm{mM} \mathrm{MgCl}_{2}$, $0.5 \mathrm{mM} \mathrm{CaCl}_{2}$ ) for $2 \mathrm{~h}$ at $37{ }^{\circ} \mathrm{C}$, followed by treatment with proteinase $\mathrm{K}(100 \mathrm{mg} / \mathrm{ml})$ in TE buffer containing $1 \%$ SDS at $50{ }^{\circ} \mathrm{C}$ for overnight, then washed with TE buffer for three times each at 15 min interval. Then plugs were sliced into appropriate sizes, treated with EcoRI restriction enzyme and subjected to FIGE. FIGE was performed with $1 \%$ agarose gel in a CHEF MAPPER (Bio-Rad Laboratories) where the initial and final switch times were set at 0.11 and $0.92 \mathrm{~s}$, respectively. Total run time was $19 \mathrm{~h}$ with $9.0 \mathrm{~V} / \mathrm{cm}$ (forward) and $6.0 \mathrm{~V} / \mathrm{cm}$ (reverse) at a constant temperature of $14{ }^{\circ} \mathrm{C}$. The gel was stained with ethidium bromide to visualize DNA bands. Presence of $s t x_{2}$ in different phage FIGE patterns was carried out by Southern blotting using the radioactively labeled $s t x_{2}$ gene probe following standard methods [29]. Both TNP positive (M18, M133, M163 and G51) and negative (G71) strains producing high titre of Stx2, were analysed to find if there is any differences between phages from these two types of strains. Along with these 5 isolates, another 5 isolates (C96, M143, M168, M171, M173) with little or no toxin producing capacity were analyzed to determine if there is any association between toxin production and inducibility of phages (with and without MMC).

\section{Evaluation of the ability of the induced phages to infect different host strains}

The following bacterial strains were used to evaluate the infectivity of inducible stx $x_{2}$ phages: $E$. coli $\mathrm{K}-12, E$. coli MC1061, E. coli DH5 $\alpha$ and clinical isolates of Shigella sonnei sh2, Shigella flexneri 1b 212,789, S. flexneri 2a 212,710, S. flexneri 2b KH-000151, S. flexneri 3a 212,670, S. flexneri 3b $\mathrm{KH}-000142$, S. flexneri $4 \mathrm{KH}-000221$, Shigella dysenteriae 1 K-235, S. dysenteriae 2 K-309, S. dysenteriae 3 K-359, S. dysenteriae 4 K-1035, Salmonella Paratyphi b 212,693, Vibrio cholerae O1 206,052, enteropathogenic E. coli W56C3. One hundred microliter of phage lysate and $500 \mu \mathrm{l}$ of exponential-phase culture of each host strain were mixed with $6 \mathrm{ml}$ of LB soft agar (containing 0.7\% agar) supplemented with $5 \mathrm{mM} \mathrm{CaCl}_{2}$ and overlaid on LB agar (containing $1.5 \%$ agar) [10]. Then the plates were incubated at $37{ }^{\circ} \mathrm{C}$ for $18 \mathrm{~h}$ and were examined for the presence of lysis zone or for plaques. The plaques were transferred to a nylon membrane (Hybond- N+, Amersham Pharmacia Biotech) according to the standard procedure [30] and hybridized at $65{ }^{\circ} \mathrm{C}$ with digoxigenin (DIG)-labelled $s t x_{2}$ probe. To prepare the $s t x_{2}$ probe, a 372-bp DNA fragment of the $s t x_{2}$ gene was purified by using a DNA purification kit (Qiagen Kit) and the purified product was labeled with DIG according to the manufacturer's instructions (Roche Diagnostics, Barcelona, Spain). Stringent hybridization was carried out with the DIG-DNA Labelling and Detection kit (Roche Diagnostics) according to the manufacturer's instructions.

\section{Construction of lysogens}

To assess the lysogenization ability of $s t x_{2}$ phages we used different bacterial strains, including E. coli MC1061, S. sonnei and E. coli DH5 $\alpha$. Three hundred microlitres of an exponential-phase culture of host strain was added to $30 \mu \mathrm{l}$ of $1 \mathrm{M} \mathrm{CaCl}_{2}$ and $6 \mathrm{ml}$ molten LB top agar (LB broth with $0.7 \%$ agar); the mixture was then poured onto LB agar plates and allowed to solidify. Twenty microlitres of a suspension of each phage lysate was spotted onto the plates. After overnight incubation at $37{ }^{\circ} \mathrm{C}$, the $\mathrm{LB}$ soft agar overlay was removed and resuspended in $1 \mathrm{ml} \mathrm{SM}$ buffer [10 mM Tris-Cl (pH 7.5), $10 \mathrm{mM} \mathrm{MgCl}_{2}, 100 \mathrm{mM}$ $\mathrm{NaCl}, 0.1 \%$ Gelatin] [30]. The mixture was incubated for $90 \mathrm{~min}$ at $37^{\circ} \mathrm{C}$, and then $0.1 \mathrm{ml}$ portions of 10 -fold dilutions in phosphate-buffered saline were plated onto LB agar. The plates were incubated at $37^{\circ} \mathrm{C}$ for overnight. Lysogeny of bacterial hosts carrying the $s t x_{2}$ gene were identified by colony hybridization method as described previously [31] with stx $x_{2}$ probe used in the plaque blot hybridization. The presence of $s t x_{2}$ genes in lysogenic bacteria was confirmed by PCR. The production of Stx 2 by the lysogenic strains was tested using a commercially available RPLA kit (VTEC-RPLA, Oxoid ltd, UK). Finally, PFGE of XbaI digested total chromosomal DNA of lysogenic strains were done along with host strain $(E$. coli MC1061) and Stx2-producing isolate (G51) from which bacteriophage was isolated. PFGE banding patterns of the lysogenic strain were compared with that of the corresponding non-lysogenic host strain to determine possible changes in the band-patterns due to integration of phage DNA into the chromosome of the host strain. To further confirm the integration of phage DNA in the chromosome of the host strain, relevant bands were excised from PFGE gel and the DNA was extracted by Montage Gel Extraction Kit (Merck Millipore) according to manufacturer's instructions. The extracted DNA was then subjected to PCR assays for $s t x_{2}$ gene to test for the presence of the phage genome.

\section{Results}

Majority of E. coli 0157 isolates are non-toxigenic despite carrying virulence genes

Despite being positive for $s t x_{2}$ gene, 42 out of $47 \mathrm{E}$. coli O157 (89\%) produced no (Stx2 titre: <2) or lower level of toxin (Stx2 titre: 8 to 32) and the remaining 5 isolates (11\%) produced high titre of Stx2 toxin (Stx2 titre: 64 to 128) in VTEC RPLA assay [32]. Of the 5 isolates, 2 and 3 isolates were obtained from goat feces and buffalo feces, respectively (Table 1). None of the isolates except for one (C35) were positive for st $x_{1}$ gene, and all isolates were positive for other virulence genes including eae, katP, $e t p D$ and $h l y_{\text {EHEC }}$ genes. All isolates were negative for $c d t$ gene. Subtyping of $s t x_{2}$ gene revealed that 46 of 47 isolates were carrying both $s t x_{2 \mathrm{a}}$ and $s t x_{2 \mathrm{~d}}$ and remaining isolate 
Table 1 Characteristics of Shiga toxin-producing E. coli $\mathrm{O} 157$ isolated from food and food-producing animals

\begin{tabular}{|c|c|c|c|c|c|c|c|c|c|c|c|c|c|}
\hline \multirow[t]{2}{*}{ ID no. } & \multirow[t]{2}{*}{ Source } & \multirow[t]{2}{*}{$s t x_{2}^{a}$} & \multirow{2}{*}{$\begin{array}{l}\text { Stx }_{2} \\
\text { titre }\end{array}$} & \multirow[t]{2}{*}{$c d t^{a}$} & \multicolumn{4}{|c|}{ TNP $^{a}$} & \multirow{2}{*}{$\begin{array}{l}N^{a} M^{a} \\
P C R\end{array}$} & \multirow{2}{*}{$\begin{array}{l}Q_{933} / \\
Q_{21}{ }^{d}\end{array}$} & \multirow{2}{*}{$\begin{array}{l}\text { Presence } \\
\text { of } s t x_{2} \\
\text { subtypes }\end{array}$} & \multicolumn{2}{|c|}{ Phage integration site } \\
\hline & & & & & A & $B$ & C & $\bar{D}$ & & & & yehV & $w r b A$ \\
\hline $\mathrm{C} 8$ & Cow & + & $-\mathrm{b}$ & - & + & + & + & + & + & $Q_{21}$ & $s t x_{2 a}, s t x_{2 d}$ & 1 & 1 \\
\hline C21 & Cow & + & - & - & + & + & + & + & + & $Q_{21}$ & $s^{\prime} x_{2 a} s t x_{2 d}$ & । & 1 \\
\hline C35 & Cow & + & - & - & + & + & + & + & + & $Q_{21}$ & $s x_{2 a}, s t x_{2 d}$ & I & 1 \\
\hline C61 & Cow & + & - & - & + & + & + & + & + & $Q_{21}$ & $s t x_{2 a}, s t x_{2 d}$ & । & 1 \\
\hline C62 & Cow & + & 2 & - & + & + & + & + & + & $Q_{21}$ & $s t x_{2 a} s t x_{2 d}$ & । & 1 \\
\hline C96 & Cow & + & - & - & + & + & + & + & + & $Q_{21}$ & $s t x_{2 a}, s t x_{2 d}$ & I & 1 \\
\hline C106 & Cow & + & - & - & + & + & + & + & + & $Q_{21}$ & $s t x_{2 a} s t x_{2 d}$ & 1 & 1 \\
\hline C111 & Cow & + & - & - & + & + & + & + & + & $Q_{21}$ & $s t x_{2 a}, s t x_{2 d}$ & I & I \\
\hline C118 & Cow & + & - & - & + & + & + & + & + & $Q_{21}$ & $s t x_{2 a} s t x_{2 d}$ & 1 & 1 \\
\hline M2 & Buffalo & + & - & - & + & + & + & + & + & $Q_{21}$ & $s t x_{2 a} s t x_{2 d}$ & Variant- $R$ & I \\
\hline M18 & Buffalo & + & 64 & - & + & + & + & + & + & $Q_{21}$ & $s t x_{2 a}, s t x_{2 d}$ & I & I \\
\hline M21 & Buffalo & + & - & - & + & + & + & + & + & $Q_{21}$ & $s t x_{2 a} s t x_{2 d}$ & I & 1 \\
\hline M29 & Buffalo & + & - & - & + & + & + & + & + & $Q_{21}$ & $s t x_{2 a} s t x_{2 d}$ & I & 1 \\
\hline M34 & Buffalo & + & - & - & + & + & + & + & + & $Q_{21}$ & $s^{\prime} x_{2 a}, s t x_{2 d}$ & 1 & 1 \\
\hline M42 & Buffalo & + & - & - & - & + & + & + & + & $Q_{21}$ & $s t x_{2 a} s t x_{2 d}$ & I & 1 \\
\hline M52 & Buffalo & + & - & - & - & - & - & - & + & $Q_{21}$ & $s t x_{2 a}, s t x_{2 d}$ & I & 1 \\
\hline M58 & Buffalo & + & - & - & + & + & + & + & + & $Q_{21}$ & $s t x_{2 a}, s t x_{2 d}$ & I & I \\
\hline M64 & Buffalo & + & 2 & - & + & + & + & + & + & $Q_{21}$ & $s t x_{2 a} s t x_{2 d}$ & I & 1 \\
\hline M98 & Buffalo & + & - & - & + & + & + & + & + & $Q_{21}$ & $s^{\prime} x_{2 a}, s t x_{2 d}$ & 1 & 1 \\
\hline M103 & Buffalo & + & 2 & - & + & + & + & + & + & $Q_{21}$ & $s t x_{2 a} s t x_{2 d}$ & 1 & 1 \\
\hline M112 & Buffalo & + & 8 & - & + & + & + & + & + & $Q_{21}$ & $s t x_{2 a}, s t x_{2 d}$ & I & 1 \\
\hline M126 & Buffalo & + & 2 & - & + & + & + & + & + & $Q_{21}$ & $s t x_{2 a} s t x_{2 d}$ & 1 & 1 \\
\hline M129 & Buffalo & + & 32 & - & + & + & + & + & + & $Q_{21}$ & $s t x_{2 a} s t x_{2 d}$ & Variant- $R$ & 1 \\
\hline M133 & Buffalo & + & 128 & - & + & + & + & + & + & $Q_{21}$ & $s t x_{2 a}, s t x_{2 d}$ & I & 1 \\
\hline M139 & Buffalo & + & - & - & + & + & + & + & + & $Q_{21}$ & $s t x_{2 a} s t x_{2 d}$ & I & 1 \\
\hline M143 & Buffalo & + & 32 & - & + & + & + & + & + & $Q_{21}$ & $s t x_{2 a}, s t x_{2 d}$ & 1 & 1 \\
\hline M163 & Buffalo & + & 128 & - & + & + & + & + & + & $Q_{21}$ & $s t x_{2 a} s t x_{2 d}$ & 1 & 1 \\
\hline M168 & Buffalo & + & 2 & - & + & + & + & + & + & $Q_{21}$ & $s t x_{2 a} s t x_{2 d}$ & I & 1 \\
\hline M171 & Buffalo & + & 16 & - & + & + & + & + & + & $Q_{21}$ & $s t x_{2 a}, s t x_{2 d}$ & Variant-R & 1 \\
\hline M173 & Buffalo & + & 16 & - & + & + & + & + & + & $Q_{21}$ & $s t x_{2 a} s t x_{2 d}$ & I & 1 \\
\hline G10 & Goat & + & 2 & - & + & + & + & + & + & $Q_{21}$ & $s t x_{2 a}, s t x_{2 d}$ & I & 1 \\
\hline G51 & Goat & + & 64 & - & + & + & + & + & + & $Q_{21}$ & $s t x_{2 a} s t x_{2 d}$ & Variant-R & 1 \\
\hline G56 & Goat & + & - & - & - & + & + & - & + & - & $s t x_{2 a} s t x_{2 d}$ & O & 1 \\
\hline G61 & Goat & + & 2 & - & + & + & + & - & + & - & $s t x_{2 a}, s t x_{2 d}$ & Variant- $R$ & 1 \\
\hline G63 & Goat & + & 16 & - & + & + & + & - & + & - & $s t x_{2 a} s t x_{2 d}$ & Variant-R & 1 \\
\hline G67 & Goat & + & - & - & + & + & + & + & + & $Q_{21}$ & $s t x_{2 a}, s t x_{2 d}$ & $\mathrm{O}$ & 1 \\
\hline G71 & Goat & + & 128 & - & + & + & + & - & + & - & $s t x_{2 a}, s t x_{2 d}$ & Variant-R & 1 \\
\hline G72 & Goat & + & 2 & - & + & + & + & + & + & $Q_{21}$ & $s t x_{2 a} s t x_{2 d}$ & I & I \\
\hline G85 & Goat & + & 2 & - & + & + & + & + & + & $Q_{21}$ & $s t x_{2 a}, s t x_{2 d}$ & 1 & 1 \\
\hline G99 & Goat & + & - & - & + & + & + & + & + & $Q_{21}$ & $s t x_{2 a} s t x_{2 d}$ & 1 & 1 \\
\hline $\mathrm{CM} 2$ & Beef & + & - & - & + & + & + & + & + & $Q_{21}$ & $s t x_{2 a} s t x_{2 d}$ & I & 1 \\
\hline CM5 & Beef & + & - & - & + & + & + & + & + & $Q_{21}$ & $s t x_{2 a} s t x_{2 d}$ & $\mathrm{O}$ & 1 \\
\hline CM7 & Beef & + & - & - & + & + & + & + & + & $Q_{21}$ & $s^{\prime} x_{2 a}, s t x_{2 d}$ & O & 1 \\
\hline
\end{tabular}


Table 1 Characteristics of Shiga toxin-producing E. coli O157 isolated from food and food-producing animals (Continued)

\begin{tabular}{|c|c|c|c|c|c|c|c|c|c|c|c|c|c|}
\hline \multirow[t]{2}{*}{ ID no. } & \multirow[t]{2}{*}{ Source } & \multirow[t]{2}{*}{$s t x_{2}^{a}$} & \multirow{2}{*}{$\begin{array}{l}\mathrm{Stx}_{2} \\
\text { titre }\end{array}$} & \multirow[t]{2}{*}{$c d t^{a}$} & \multicolumn{4}{|c|}{ TNP ${ }^{a}$} & \multirow{2}{*}{$\begin{array}{l}\mathrm{NM}^{\mathrm{a}} \\
\mathrm{PCR}\end{array}$} & \multirow{2}{*}{$\begin{array}{l}Q_{933} / \\
Q_{21}\end{array}$} & \multirow{2}{*}{$\begin{array}{l}\text { Presence } \\
\text { of stx } 2 \\
\text { subtypes }\end{array}$} & \multicolumn{2}{|c|}{ Phage integration site } \\
\hline & & & & & $A$ & $B$ & C & $\bar{D}$ & & & & yehv & $w r b A$ \\
\hline CM52 & Beef & + & - & - & + & + & + & + & + & $Q_{21}$ & $s t x_{2 a}, s t x_{2 d}$ & । & I \\
\hline CM56 & Beef & + & - & - & + & - & + & + & - & - & $s t x_{2 a} s t x_{2 d}$ & । & I \\
\hline MM27 & Buf Meat $^{c}$ & + & - & - & + & + & + & + & + & $Q_{21}$ & $s t x_{2 a} s t x_{2 d}$ & । & I \\
\hline MM28 & Buf Meat $^{c}$ & + & - & - & + & - & + & + & - & - & $s t x_{2 d}$ & । & I \\
\hline E. coli NCTC12079 & Clinical isolate & + & 128 & - & - & - & - & - & - & $Q_{933}$ & $N D^{f}$ & $N D^{f}$ & \\
\hline
\end{tabular}

${ }^{a}$ Examined by PCR method. + , positive; - , negative

${ }^{b}$ Stx2 toxin detection. -, not detected

'Buffalo meat

dPresence of either $Q_{933}$ or $Q_{21}$ gene. -, absence of both genes

I, intact; $\mathrm{O}$, occupied. 'Intact' indicates detection of neither junction. 'Variant- $\mathrm{R}^{\prime}$ indicates that the left junction between the bacteriophage and the chromosome was detected but the right junction was not detected. 'Occupied' indicates bilateral detection of that integration site

${ }^{f}$ Not Done

was positive for $s t x_{2 \mathrm{~d}}$ only. All isolates were negative for $s t x_{2 \mathrm{~b}}, s t x_{2 \mathrm{c}}, s t x_{2 \mathrm{e}}, s t x_{2 \mathrm{f}}$ and $s t x_{2 \mathrm{~g}}$.

\section{PCR assays demonstrated that $E$. coli 0157 isolates carry} non-functional promoter sequence in the stx region

Thirty nine out of 47 isolates were positive for all four genes specific for TNP region (Table 1). Of the remaining 8 isolates, 7 were positive for either one or three out of 4 genes and one isolate was negative for all 4 genes. Presence of all 4. TNP genes indicates that the isolates have a non-functional promoter sequence in the Stx region [23]. Forty five out of 47 isolates were positive for NM specific PCR. Forty-one of 47 isolates were positive for $Q_{21}$ gene. All the 5 isolates that were negative for $Q_{21}$ gene were partially negative for TNP genes. None of the 47 isolates were positive for $Q_{933}$ gene (Table 1).

\section{yehV and wrbA phage insertion sites were intact in majority of $E$. coli 0157 isolates}

Of the 47 E. coli $\mathrm{O} 157$ isolates, 11 did not produce any amplicon for $y e h V$ gene, indicating that this site maybe occupied by a bacteriophage (Table 1). Insertion of phages in this site was further confirmed by detecting regions spanning from left and right junctions of the insertion to bacteriophages. Of the 11 isolates, four were positive for amplification of the left and right $y e h V$-bacteriophage junction and the remaining seven isolates were positive for the left but not the right yeh $V$-bacteriophage junction. All isolates had amplification of $w r b A$ gene indicating that this site is intact in all the isolates. Intact $w r b A$ site was further confirmed by the absence of any amplification in the left and right wrbA-bacteriophage junction.

Only toxin-producing isolates carried inducible stx phages Growth kinetics of isolates varied from each other when cells were induced with MMC. Some isolates contained phages that were inducible and the level of induction varied from isolate to isolate (Fig. 1). Significant reduction of growth of M163 isolate was observed when cultured with MMC as compared to growth without MMC (Fig. 1a). This is comparable with the growth pattern of the positive control strain E. coli O157:H7 NCTC 12079 (contain both $s t x_{1}$ and $s t x_{2}$ gene) (Fig. 1b). For both isolates, when culture was done with $\mathrm{MMC}$, multiplication of cells occurred at same level up to the first $2 \mathrm{~h}$ and cell growth was stationary at that level for the next $2 \mathrm{~h}$ followed by rapid decline of growth within next $1 \mathrm{~h}$. In the case of MMC free culture, cell growth kept on rising at the same rate. At $7 \mathrm{~h}$ point, OD (at $600 \mathrm{~nm}$ ) of MMC added culture came down to zero while in case of culture without MMC, it increased up to 1.5. In the case of M18, M133, G51 and G71, bacterial growth in presence of MMC was also slowed down as compared to growth without MMC but the complete cessation of growth was not observed (Fig. 1c). In contrast, for toxin non-producing isolate M103, cell growth increased in the first $5 \mathrm{~h}$ for MMC added culture then became relatively stable, although cell growth increased at a normal rate for MMC free culture (Fig. 1d).

\section{stx 2 phages carried by Shiga toxin-producing E. coli 0157 isolates are genetically clustered}

Field Inversion Gel Eelectrophoresis (FIGE) analysis of phage DNA revealed diversity among phages induced from different $E$. coli $\mathrm{O} 157$ isolates. Based on the number of bands detected in FIGE analysis of undigested phage DNA, we found that all the four TNP positive isolates that produce high titre of toxins (M18, M133, M163 and G51) carried more than one bacteriophage. Digestion of phage DNA with EcoR1 restriction enzyme produced multiple bands (4 to 14) and banding patterns were different from one phage to another (Fig. 2A1). Digested phage DNA was transferred to nylon membrane and hybridized with radioactively labeled $s t x_{2}$ probe in order to specify the location of $s t x_{2}$ gene within 

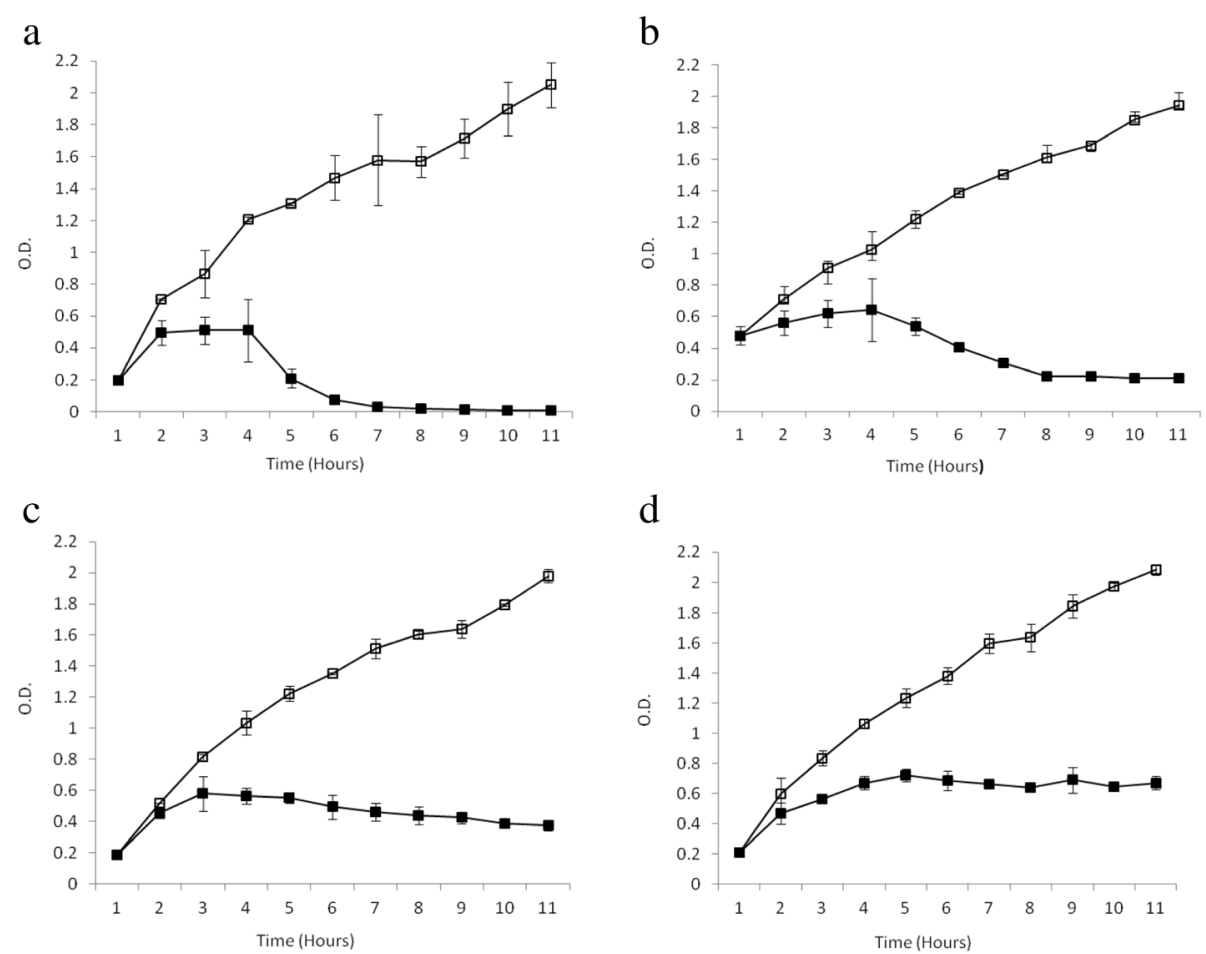

Fig. 1 Kinetics of phage induction in toxin-producing and toxin non-producing E. coli O157 isolates. Two toxin-producing E. coli O157 strains (a M163; c M18) along with one toxin negative E. coli O157 strain (d M103) and positive control strain E. coli O157:H7 (b NCTC 12079) were used. Each culture was grown to an opitical density (OD) of 0.2 at $600 \mathrm{~nm}$ and then separated into two aliquots, one was treated with mitomycin C (and the other one was not $(\square)$ and bacterial cell growth in both aliquots were followed at every $1 \mathrm{~h}$ interval upto $11 \mathrm{~h}$. OD data (Y-axis) were plotted against time in $\mathrm{h}$ (X-axis). Error bars depict standard errors of the means of three replicas

phage DNA. Positive signals were found in case of four phages, where $s t x_{2}$ probe was hybridized with a single band of $5.5 \mathrm{~kb}$ in size. G71, the TNP negative strain that produce high titre of toxin, also carried more than one phages and $s t x_{2}$ probe was hybridized with a single band of $6 \mathrm{~kb}$ in size (Fig. 2A2). The hybridization results indicate that all of the five E. coli O157:H7 strains carry non-stx phages in addition to stx phages.

Phage DNA extracted from $E$. coli isolates having different toxin-producing capacity [high $(\geq 64)$, low $(\leq 32)$ or no titre $(<2)$ of toxins] with and without MMC induction were analysed by FIGE to determine if there is any association between toxin production and inducibility of phages. Considerable increase in intensity of $s t x_{2}$ phage DNA (and thus replication) was observed after MMC induction of isolates that produced relatively high titre of toxin (Fig. 2B1). Presence of $s t x_{2}$ in these phages was confirmed by PCR and hybridization with $s t x_{2}$ gene probe (Fig. 2B2). Similar level of increase in phage DNA intensity was also observed in case of little or no toxin producing isolates (C96, M143, M168, M171, M173) (Fig. 2C1) but these inducible phages were not $s t x_{2}$-carrying as none of phage DNA gave positive signal in Southern hybridization with $s t x_{2}$ probe (Fig. 2C2).

\section{$s t x_{2}$ phages induced from STEC 0157 isolates can infect diverse host strains}

The ability of induced $s t x_{2}$-phages to infect different hosts was analysed by plaque-forming assay and by hybridization of the plaques with a 372-bp stx $x_{2}$ gene probe (Table 2). All $s t x_{2}$-phages induced from STEC originated from buffalo (M18, M133, M163) infected clinical isolate of S. sonnei but the phages induced from isolates originated from goat (G51, G71) could not infect S. sonnei. E. coli MC1061, DH5 $\alpha$ and $S$. dysenteriae 4 were infected by three phages each (Table 2). Phage induced from M133 infected E. coli O157:H7 NCTC 12900 (Stx negative), while phage induced from the control E. coli O157:H7 NCTC 12079 isolate infected E. coli MC1061 and S. sonnei. Although clear infection of $S$. dysenteriae type 2 (data not shown) and type 4 was observed with phages from M163 and G71 isolates, respectively but these plaques were negative in plaque blot hybridization assay with $s t x_{2}$ probe suggesting that isolates carrying inducible phages other than $s t x_{2}$ phage.

\section{$s t x_{2}$ phage induced from one STEC 0157 isolate lysogenized different bacterial strains}

The ability of $s t x_{2}$ phages to infect and lysogenize different susceptible bacterial strains was assessed. Phage induced from isolates G51 successfully lysogenized E. coli MC1061, 
A1

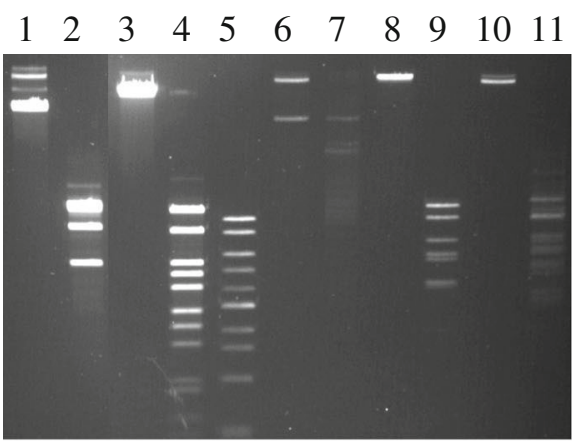

A2

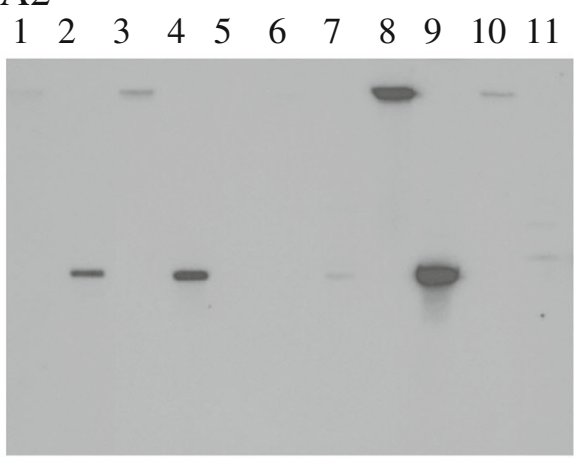

B1

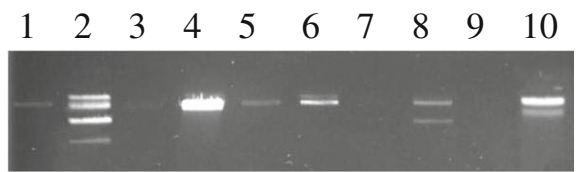

B2

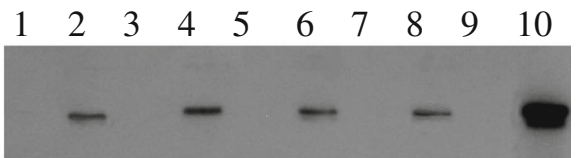

C1

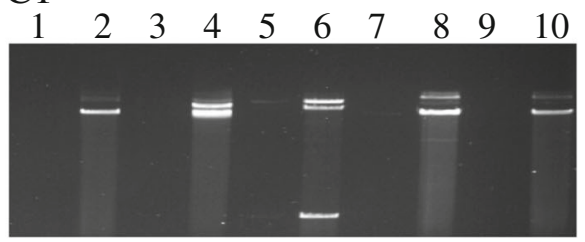

C2

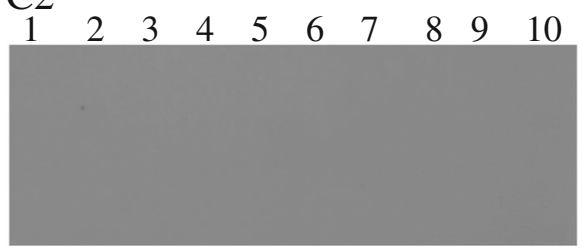

Fig. 2 Field inversion gel electrophoresis (FIGE) analysis of phage DNA. (A1) FIGE analysis of EcoRI- digested phage DNA induced from toxinproducing $\mathrm{E}$. coli $\mathrm{O} 157$ isolates and (A2) its corresponding blot hybridized with radioactively labeled stx 2 probe. Lane 1: M18 (undigested), Lane 2: M18 (digested), Lane 3: M133 (undigested), Lane 4: M133 (digested), Lane 5: 1 kb Marker, Lane 6: M163 (undigested), Lane 7: M163 (digested), Lane 8: G51 (undigested), Lane 9: G51 (digested), Lane 10: G71 (undigested), Lane 11: G71 (digested). (B1) FIGE analysis of phage DNA induced

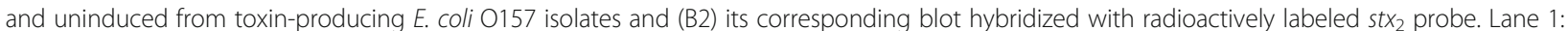
M18 (uninduced), Lane 2: M18 (induced), Lane 3: M133 (uninduced), Lane 4: M133 (induced), Lane 5: G71 (uninduced), Lane 6: G71 (induced), Lane 7: M163 (uninduced), Lane 8: M163 (induced), Lane 9: G51 (uninduced), Lane 10: G51 (induced). (C1) FIGE analysis of phage DNA induced and uninduced from E. coli $\mathrm{O} 157$ isolates producing little or no toxin and (C2) its corresponding blot hybridized with radioactively labeled stx probe. Lane 1: C96 (uninduced), Lane 2: C96 (induced), Lane 3: M143 (uninduced), Lane 4: M143 (induced), Lane 5: M168 (uninduced), Lane 6: M168 (induced), Lane 7: M171 (uninduced), Lane 8: M171 (induced), Lane 9: M173 (uninduced), Lane 10: M173 (induced)

which was stable after repeated sub-cultivation of the transduced strain. The lysogenized strain produced high titre of Stx2 toxin in VTEC-RPLA assay (toxin titre 64). None of the phages from remaining isolates was found to lysogenize bacterial hosts. PFGE banding pattern of phage integrated host strain was almost identical with that of phage non-integrated strain except for disappearance of an $80 \mathrm{~kb}$ band in the lysogenized strain along with the intensification of a $140 \mathrm{~kb}$ band, which is indicative of the integration of phage DNA into bacterial host chromosome (Fig. 3). For further confirmation of integration, we excised the intensified band of lysogenic strain and its corresponding band in host strain (E. coli MC1061), extracted DNA from the gel and did PCR for $s t x_{2}$ gene. We also excised the $80 \mathrm{~kb}$ band

Table 2 Infectivity of toxin-producing stx 2 phages in different bacterial host

\begin{tabular}{|c|c|c|c|c|c|c|}
\hline \multirow[t]{2}{*}{ Bacterial species } & \multicolumn{6}{|c|}{ Phage ID number } \\
\hline & $\Phi 12079$ & ФM133 & ФM163 & ФG71 & ФM18 & ФG51 \\
\hline Shigella sonnei & + & + & + & - & + & - \\
\hline E. coli MC1061 & + & - & + & + & - & + \\
\hline E. coli DH5a & - & - & + & + & - & + \\
\hline S. dysenteriae type 4 & - & + & - & $-{ }^{a}$ & + & - \\
\hline E. coli O157:H7 NCTC12900 & - & + & - & _- & - & _- \\
\hline
\end{tabular}

+ , Strong signal; -, no signal after hybridization of the plaque with the specific stx $x_{2}$-probe

${ }^{a} \Phi G 71$ produced clear plaques on culture lawn of $S$. dysenteriae type 4 but these plaques did not give positive signal in plaque blot hybridization assay with st $x_{2}$-probe 


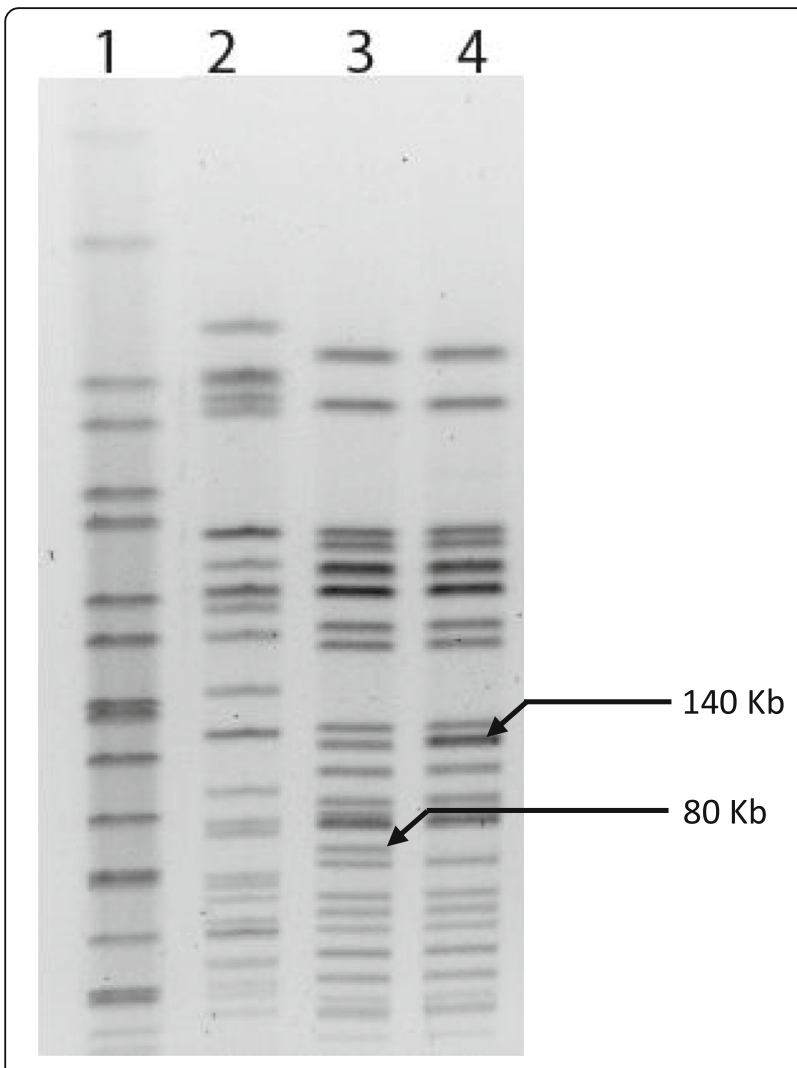

Fig. 3 Detection of integration of $s t x_{2}$ phage DNA with E. coli MC1061 chromosome by PFGE analysis. Lane 1: Salmonella Braenderup, Lane 2: E. coli O157 G51, Lane 3: E. coli MC1061, Lane 4: E. coli MC1061Lysogen. The bottom arrow mark denotes the position of the band in $E$. coli MC1061 which is missing in all lysogenic strains of E. coli MC1061. The arrow mark above denotes the intensity of a band in all lysogenic strains of E. coli MC1061 which is significantly higher than that of the non-lysogenic E. coli MC1061 strain

from the host strain and did PCR for $s t x_{2}$ gene using template DNA extracted from gel. Only the intensified $140 \mathrm{~kb}$ band from lysogen was found positive for $s t x_{2}$ gene while none of the $140 \mathrm{~kb}$ and $80 \mathrm{~kb}$ bands in host strain (E. coli $\mathrm{MC1061)}$ was positive demonstrating the integration of $s t x_{2}$ gene in the bacterial chromosome.

\section{Discussion}

Previous studies have demonstrated that E. coli O157 isolates of cattle origin, particularly from Asian countries, contain defective stx phages and, therefore, cannot produce sufficient amounts of toxin required to cause severe human infection [23]. In this study, we found that the majority (89\%) of E. coli O157 isolates from food or food-producing animal (cattle) origin have little or no ability to produce Shiga toxin in spite of being positive for the stx gene. This could be one of the reasons for a low prevalence of E. coli $\mathrm{O} 157$ infection in humans in Bangladesh [33]. As the most important virulence factor of E. coli $\mathrm{O} 157$ is Stx2 and adhesin intimin; the role of other virulence factor such as enterohaemolysin, a serine protease (EspP) and catalase or peroxidase (KatP) in causing infection in human may be low [34]. Lower prevalence of E. coli $\mathrm{O} 157$ infection in humans have also been reported from other Asian countries including Thailand and Malaysia [18, 19]. However, unlike Thailand and Malaysian studies, we found that a number of isolates $(n=5 ; 11 \%)$ can produce high titre of Stx2 using the VTEC-RPLA assay. We analysed these isolates for a set of four PCR-amplifiable genetic loci as markers that were previously reported to be linked with toxin non-producing (TNP) characteristics of E. coli O157. We found that most of the isolates were positive for these four genetic markers whereas a few isolates showed negative results for one or two of these markers. Among the 5 isolates that were capable of producing high titre of toxins, four were positive for TNP PCR, which is not in agreement with the previous study [23]. Although in that study [23], a small number of TNP positive isolates were found to produce Stx, the level of toxin production was much lower than that of Stx positive and TNP negative isolates. Subsequently, in another study, a high number of TNP positive human isolates were found to produce a high titre of Stx [24]. Therefore, the application of TNP PCR for detecting toxin non-producing isolates needs further evaluation. Considering this pitfall of TNP PCR, Taylor et al. [24] recommended that detection of bacteriophage antiterminator gene alleles $Q_{933}$ and $Q_{21}$ could be a better marker for the detection of TNP strains from both human and animal origins. Previous studies demonstrated that E. coli O157:H7 strains harboring the antiterminator gene variant $Q_{933}$ produced significantly higher levels of Stx2 than strains with the $Q_{21}$ variant [12]. None of the isolates in the present study was positive for $Q_{933}$, although 5 isolates produced moderate to high level of Stx, in contrast with the previous study [12]. All of these four isolates producing high titre Shiga toxin were positive for $Q_{21}$, which is also not in agreement with previous reports $[12,35]$, although a majority of toxin negative isolates were found positive for $Q_{21}$. In sum, none of the PCR methods developed to date is $100 \%$ specific for detecting toxin non-producing isolates and thus toxin assay is still the most reliable approach.

Typing of Stx2 provides important epidemiological characteristics of STEC isolates. In this study, we found that all isolates, except for one, carried a combination of $s t x_{2 \mathrm{a}}$ and $s t x_{2 \mathrm{~d}}$ subtypes. STEC strains carrying more than one $s t x_{2}$ subtypes have been reported in previous studies [25, 36]. According to previous study, the combination of Stx2a and Stx2d were more potent than Stx2b, Stx2c and Stx1 in both cell culture and animal models [37]. However, epidemiological data suggest that 
STEC O157 strains carrying Stx2a and Stx2c are most commonly associated with HUS in humans [36, 38, 39].

Analysis of phage integration sites in E. coli $\mathrm{O} 157$ showed that only a few isolates have Stx2 phage integration sites at yehV and all isolates have intact wrbA site, which is inconsistent with previous study where wrbA was found to be the most commonly occupied site by Stx2 encoding bacteriophages [27]. Nevertheless, some studies suggested that $y e h V$ is commonly occupied by bacteriophages in E. coli O157 isolated from cattle [40]. It has also been reported that strains carrying $s t x_{2}$ phages at $y e h V$ site were amplification-positive for the left but not the right yehV junction, a characteristic more commonly seen in cattle isolates compared to the clinical isolates [41]; corroborating with isolates in this study. Nonetheless, phage occupancy was not detected in either of yehV and wrbA sites in a significant number of isolates, accentuating the need for further exploration of isolates for the presence of other insertion sites.

In order to get more insight into characteristics of TNP E. coli O157 isolates, we examined the inducibility of stx phages present in these isolates. Apart from being the reservoir of main virulence factors of STEC, stx phages are involved in the regulation of pathogenicity factors and the development of genomic plasticity of host bacteria [42]. Among virulent E. coli O157 strains, high titre of toxin production is coupled with the production of infectious phage particles [23]. TNP isolates cannot produce a high titre of toxin due to the poor expression of late phage genes from the $p_{R^{\prime}}$ promoter [23]. However, in our study we found that four TNP PCR positive isolates were able to produce complete phage particles after MMC induction. For the induction assay, we used E. coli O157:H7 12,079 as a control which carries MMC inducible stx phage. Complete cessation of bacterial growth was observed in this isolate within $10 \mathrm{~h}$ of MMC treatment. Comparing the degree of induction of phages in E. coli O157:H7 12,079 with phages in cattle isolates, we found that phages in M163 had the same degree of induction with E. coli O157:H7 12,079 strain while phages in M133, M18, G51 and G71 were inducible at a relatively slower rate (Fig. 1).

PCR confirmed the presence of $s t x_{2}$ gene in induced phage DNA extracted from all five isolates. EcoR1 digestion of phage DNA revealed a high degree of heterogeneity among DNA bands in FIGE indicating a considerable diversity of phage genomes. However, the heterogeneity was not seen in hybridization of $s t x_{2}$ gene as a single band of similar size was found to be hybridized with most of the phage DNA samples. The heterogeneity in EcoR1 digested phage DNA might be due to the presence of non-stx phages present in the isolates.

Horizontal gene transfer plays a major role in virus evolution by creating new combinations of genetic material through pairing and shuffling of related DNA sequences [42-44]. We have shown that the phages induced from 5 STEC isolates could infect a range of bacterial isolates such as E. coli DH5 $\alpha$, E. coli MC1061, clinical isolates of Shigella sonnei and S. dysenteriae type 4. More precisely, 3 of the $5 s t x_{2}$ phages could infect a clinical isolate of $S$. son$n e i$. Stx gene containing bacteriophage in S. sonnei was also reported previously and studies suggested that Shigella might play a role in spreading of stx genes [45-48]. This finding has important public health implication in Bangladesh given that the prevalence of $S$. sonnei has been increasing in patients with diarrhoea in the country [49]. A new variant of $S$. sonnei has been recently emerged, which carries all essential virulence genes needed for enteroinvasive pathogenesis along with an inducible Stx1 encoding prophage providing additional virulence potential related to Shiga toxin [50].

Among six bacteriophages used in testing lysogenic conversion of recipient bacterial strains, we identified lysogens of $s t x_{2}$ phage induced from isolate G51 in E. coli MC1061. The lysogenized strain produced a high titre of toxin similar to parent strain without MMC induction. In PFGE analysis, $\mathrm{XbaI}$ digestion of chromosomal DNA of lysogenic and non-lysogenic strains of E. coli MC1061 confirmed the integration of phage DNA to MC1061 DNA. We found that a single band of approximately $80 \mathrm{~kb}$ disappeared from lysogenic strains while another band of approximately $140 \mathrm{~kb}$ in size substantially intensified, suggesting that an additional band of similar size is present in the same position (Fig. 3). The $s t x_{2}$ phage DNA has genome sizes in the range from 49 to $66 \mathrm{~kb}$ $[10,51]$. The integration of phage genome with bacterial chromosome at the site of $80 \mathrm{~kb}$ band results in increase of the band size in the range of $129 \mathrm{~kb}$ to $146 \mathrm{~kb}$ and this is what has been identified in PFGE- the increase of intensity of $140 \mathrm{~kb}$ band in E. coli MC1061 (Fig. 3). In general, stx lysogens occur at a low frequency and all stx phages are not capable of generating lysogens at the same frequency [52] or lysogenize the same bacterial host strain [53]. stx phages induced from lysogenic strains generate lysogen rarely even under the best conditions [41].

Nearly all bacterial genomes comprise of multiple active or defective phages [54]. Prophages and integrative elements constitute about 30\% genome of STEC strains [55]. For temperate phages, prophage remnants, entrapped in host chromosome, can be a receptacle of functional lytic cycle genes [54]. Similarly, defective prophages which were known as simple genetic junk or remnants, are now recognized for a wide range of characteristics that are essential to bacterial hosts with respect to virulence, stress resistance, or even the rate of mutation [28, 55-57]. Environmental factors are known to influence the induction and transmissibility of 
lysogenic phages and the biology of bacterial strains carrying such phages. In view of predicted climatic changes likely to adversely affect various regions of the world, in particular, the low-lying Ganges delta region, marked changes in the ecology, human behavior and epidemiology of infectious diseases are likely to occur. Therefore, human pathogens which are abundant in food-producing animals may pose considerably enhanced risks of human infection under the changed settings. This accentuates further investigation of defective phages in E. coli $\mathrm{O} 157$ isolates producing no or low toxin, particularly in Asian countries where the prevalence of these organisms in the animal reservoir is high. Besides, detection of active and infectious phages with lysogenic properties in the current and previous [28, 55] studies indicated that phage mediated transfer of Stx genes from pathogenic to non-pathogenic strains can readily occur in the environment, particularly in areas polluted with animal feces carrying STEC. Our results warrant further investigations to monitor the emergence and evolution of Shiga toxin-producing organism with relevance to public health.

\section{Conclusions}

The majority of E. coli $\mathrm{O} 157$ from food and food-producing animals tested in this study are not capable of producing Shiga toxin, the main virulence factor for the organism. This might be one of the reasons that $E$. coli $\mathrm{O} 157$ infection is not prevalent in humans in Bangladesh. The non-toxigenic characteristic of $E$. coli $\mathrm{O} 157$ strains is attributed to the presence of genetically defective $s t x$ phages in isolates. Unlike non-toxigenic isolates, the study also detected a few toxin-producing isolates carrying active stx phage. Stx phages from these isolates are capable of infecting multiple bacterial hosts and producing stable lysogen in E. coli and thus converting it into a toxigenic strain. This implies that the evolution of new STEC can readily occur in the environment, particularly in areas polluted with cattle feces.

\footnotetext{
Abbreviations

DIG: Digoxigenin; FIGE: Field inversion gel electrophoresis; LB: Luria Bertani; MMC: Mitomycin C; OD: Optical density; PEG: Polyethylene glycol; PFGE: Pulsed field gel electrophoresis; RFLP: Restriction fragment length polymorphism; RPLA: Reverse passive latex agglutination assay; STEC: Shiga toxin-producing E. coli; Stx: Shiga toxin; Stx1: Shiga toxin 1; Stx2: Shiga toxin 2; TNP: Toxin non-producing
}

\section{Funding}

This research study was funded by core donors which provide unrestricted support to icddr,b for its operations and research. Current donors providing unrestricted support include: Government of the People's Republic of Bangladesh; the Department of Foreign Affairs, Trade and Development (DFATD), Canada; Swedish International Development Cooperation Agency (Sida) and the Department for International Development (UK Aid). We gratefully acknowledge these donors for their support and commitment to icddr,b's research efforts. The funders had no role in study design, data collection and analysis, decision to publish, or preparation of the manuscript.

\section{Availability of data and materials}

All data generated or analyzed during this study are included in this article.

\section{Authors' contributions}

MR and MAI conceived of and designed the structure and content of the manuscript. MR and AN did the experiments and the literature review. MR made the first draft. MR, AN, MAI, MA, SMF analyzed the results and contributed to writing. All authors contributed to the writing of the statement and agree with its content and conclusions. All authors read and approved the final manuscript.

Ethics approval and consent to participate

Not applicable.

\section{Consent for publication}

Not applicable.

\section{Competing interests}

The authors declare that they have no competing interests.

\section{Publisher's Note}

Springer Nature remains neutral with regard to jurisdictional claims in published maps and institutional affiliations.

\section{Author details}

${ }^{1}$ Enteric and Food Microbiology Laboratory, Laboratory Sciences and Services Division (LSSD), International Centre for Diarrhoeal Disease Research, Bangladesh (icddr,b), Mohakhali, Dhaka 1212, Bangladesh. ${ }^{2}$ Present Address: Department of Biology, University of Vermont, Burlington, VT 05405, USA. ${ }^{3}$ Present Address: Department of Mathematics and Natural Sciences, BRAC University, Mohakhali, Dhaka 1212, Bangladesh.

Received: 15 March 2018 Accepted: 16 August 2018

Published online: 31 August 2018

\section{References}

1. Gyles CL. Shiga toxin-producing Escherichia coli: an overview. J Anim Sci. 2007;85:E45-62. https://doi.org/10.2527/jas.2006-508.

2. Hussein HS. Prevalence and pathogenicity of Shiga toxin-producing Escherichia coli in beef cattle and their products. J Anim Sci. 2007;85:E63-72. https://doi.org/10.2527/jas.2006-421.

3. Renter DG, Sargeant JM. Enterohemorrhagic Escherichia coli O157: epidemiology and ecology in bovine production environments. Anim Health Res Rev. 2002;3:83-94

4. Mead PS, Griffin PM. Escherichia coli O157:H7. Lancet. 1998:352:1207-12.

5. Rangel JM, Sparling PH, Crowe C, Griffin PM, Swerdlow DL. Epidemiology of Escherichia coli O157:H7 outbreaks, United States, 1982-2002. Emerg Infect Dis. 2005;11:603-9.

6. Girardeau JP, Dalmasso A, Bertin Y, Ducrot C, Bord S, Livrelli V, VernozyRozand C, Martin C. Association of virulence genotype with phylogenetic background in comparison to different seropathotypes of Shiga toxinproducing Escherichia coli isolates. J Clin Microbiol. 2005;43:6098-107.

7. Unkmeir A, Schmidt H. Structural analysis of phage borne stx genes and their flanking sequences in Shiga toxin producing Escherichia coli and Shigella dysenteriae type 1 strains. Infect Immun. 2000;68:4856-64.

8. García-Aljaro C, Muniesa M, Jofre J, Blanch AR. Genotypic and phenotypic diversity among induced, st $x_{2}$-carrying bacteriophages from environmental Escherichia coli strains. Appl Environ Microbiol. 2009:75:329-36.

9. Kimmitt PT, Harwood CR, Barer MR. Toxin gene expression by Shiga toxinproducing Escherichia coli: the role of antibiotics and the bacterial SOS response. Emerg Infect Dis. 2000;6:458-65.

10. Muniesa M, Blanco JE, de Simon M, Serra-Moreno R, Blanch AR, Jofre J. Diversity of stx, converting bacteriophages induced from Shiga-toxinproducing Escherichia coli strains isolated from cattle. Microbiology. 2004; 150:2959-71.

11. Allison HE. Stx-phages: drivers and mediators of the evolution of STEC and STEC-like pathogens. Future Microbiol. 2007;2:165-74.

12. Lejeune JT, Abedon ST, Takemura K, Christi NP, Sreevatsan S. Human Escherichia coli 0157:H7 genetic marker in isolates of bovine origin. Emerg Infect Dis. 2004;10:1482-5. 
13. Strachan NJ, Dunn GM, Ogden ID. Quantitative risk assessment of human infection from Escherichia coli 0157 associated with recreational use of animal pasture. Int J Food Microbiol. 2002;75:39-51.

14. Tuttle J, Gomez T, Doyle MP, Wells JG, Zhao T, Tauxe RV, Griffin PM. Lessons from a large outbreak of Escherichia coli O157:H7 infections: insights into the infectious dose and method of widespread contamination of hamburger patties. Epidemiol Infect. 1999;122:185-92.

15. Islam MA, Mondol AS, de Boer E, Beumer RR, Zwietering MH, Talukder KA, Heuvelink AE. Prevalence and genetic characterization of Shiga toxinproducing Escherichia coli isolates from slaughtered animals in Bangladesh. Appl Environ Microbiol. 2008;74:5414-21.

16. Islam MA, Mondol AS, Azmi IJ, de Boer E, Beumer RR, Zwietering MH, Heuvelink AE, Talukder KA. Occurrence and characterization of Shiga toxinproducing Escherichia coli in raw meat, raw milk, and street vended juices in Bangladesh. Foodborne Pathog Dis. 2010;7:1381-5.

17. Liu J, Platts-Mills JA, Juma J, Kabir F, Nkeze J, Okoi C, Operario DJ, Uddin J, Ahmed $\mathrm{S}$, Alonso PL, et al. Use of quantitative molecular diagnostic methods to identify causes of diarrhoea in children: a reanalysis of the GEMS case-control study. Lancet. 2016;388:1291-301.

18. Sukhumungoon $P$, Nakaguchi $Y$, Ingviya N, Pradutkanchana J, Iwade $Y$, Seto $\mathrm{K}$, Son $\mathrm{R}$, Nishibuchi M, Vuddhakul V. Investigation of $\operatorname{stx}_{2}{ }^{+}$eae ${ }^{+}$Escherichia coli 0157:H7 in beef imported from Malaysia to Thailand. Int Food Res J. 2011:18:381-6.

19. Sukhumungoon P, Mittraparp-arthorn P, Pomwised R, Charernjiratragul W, Vuddhakul V. High concentration of Shiga toxin 1-producing Escherichia coli isolated from Southern Thailand. Int Food Res J. 2011;18:683-8.

20. Dowd SE, Williams JB. Comparison of Shiga-like toxin II expression between two genetically diverse lineages of Escherichia coli 0157:H7. J Food Prot. 2008;71:1673-8

21. Baker DR, Moxley RA, Steele MB, Lejeune JT, Christopher-Jennings J, Chen D, Hartwidge PR, Francis DH. Differences in virulence among Escherichia coli 0157: H7 strains isolated from humans during disease outbreaks and from healthy cattle. App Environ Microbiol. 2007;73:7338-46.

22. Ritchie JT, Wagner PL, Acheson DWK, Waldorlm MA. Comparison of Shiga toxin production by hemolytic-uremic syndrome-associated and bovineassociated Shiga toxin-producing Escherichia coli isolates. Appl Environ Microbiol. 2003;69:1059-66.

23. Koitabashi T, Vuddhakul V, Radu S, Morigaki T, Asai N, Nakaguchi Y, Nishibuchi M. Genetic characterization of Escherichia coli 0157:H7/-strains carrying the stx 2 gene but not producing Shiga toxin 2. Microbiol Immunol. 2006;50:135-48.

24. Taylor EV, Shi X, Alam MJ, Peterson G, Narayanan SK, Renter DG, Nagaraja TG. Genetic variations in Shiga toxin-producing abilities of bovine and human Escherichia coli O157:H7. Zoonoses Public Health. 2011;58:185-91.

25. Scheutz F, Teel LD, Beutin L, Piérard D, Buvens G, Karch H, Mellmann A, Caprioli A, Tozzoli R, Morabito S, Strockbine NA, Melton-Celsa AR, Sanchez M, Persson S, O'Brien AD. Multicenter evaluation of a sequence-based protocol for subtyping Shiga toxins and standardizing Stx nomenclature. J Clin Microbiol. 2012;50:2951-63.

26. Tóth I, Herault F, Beutin L, Oswald E. Production of cytolethal distending toxins by pathogenic Escherichia coli strains isolated from human and animal sources: establishment of the existence of a new cdt variant (type IV). J Clin Microbiol. 2003;41:4285-91.

27. Shaikh N, Tarr PI. Escherichia coli O157:H7 Shiga toxin-encoding bacteriophages: integrations, excisions, truncations, and evolutionary implications. J Bacteriol. 2003;185:3596-605.

28. Asadulghani M, Ogura Y, Ooka T, Itoh T, Sawaguchi A, Iguchi A, Nakayama K, Hayashi T. The defective prophage pool of Escherichia coli 0157: prophage-prophage interactions potentiate horizontal transfer of virulence determinants. PLoS Pathog. 2009;(5):e1000408. https://doi.org/10.1371/ journal.ppat.1000408.

29. Maniatis T, Fritsch EF, Sambrook J. Molecular cloning: a laboratory manual. Cold Spring Harbor: Cold Spring Harbor Laboratory Press; 1982.

30. Sambrook J, Russell DW. Molecular cloning: a laboratory manual. 3rd ed. Cold Spring Harbor: Cold Spring Harbor Laboratory; 2001.

31. Teel LD, Melton-Celsa AR, Schmitt CK, O'Brien AD. One of two copies of the gene for the Activatable Shiga toxin type 2d in Escherichia coli O91:H21 strain B2F1 is associated with an inducible bacteriophage. Infect Immun 2002:70:4282-91.

32. Koitabashi T, Chui S, Kamruzzaman M, Nishibuchi M. Isolation and characterization of the Shiga toxin gene (stx)-bearing Escherichia coli 0157 and non-O157 from retail meats in Shandong Province, China, and characterization of the 0157-derived stx 2 phages. J of Food Protection. 2008:71:706-13.

33. Islam MA, Heuvelink AE, de Boer E, Sturm PD, Beumer RR, Zwietering MH, Faruque ASG, Haque R, Sack DA, Talukder KA. Shiga toxin-producing Escherichia coli isolated from patients with diarrhea in Bangladesh. J Med Microbiol. 2007:56:380-5.

34. Law D. Virulence factors of Escherichia coli 0157 and other Shiga toxinproducing E. coli. J App Microbiol. 2002;88:729-45.

35. Tóth I, Schmidt H, Kardos G, Lancz Z, Creuzburg K, Damjanova I, Pászti J, Beutin L, Nagy B. Virulence genes and molecular typing of different groups of Escherichia coli 0157 strains in cattle. Appl Environ Microbiol. 2009;75: 6282-91.

36. Persson S, Olsen KE, Ethelberg S, Scheutz F. Subtyping method for Escherichia coli Shiga toxin (verocytotoxin) 2 variants and correlations to clinical manifestations. J Clin Microbiol. 2007:45:2020-4.

37. Fuller CA, Pellino CA, Flagler MJ, Strasser JE, Weiss AA. Shiga toxin subtypes display dramatic differences in potency. Infect Immun. 2011;79:1329-37.

38. Friedrich AW, Bielaszewska M, Zhang WL, Pulz M, Kuczius T, Ammon A, Karch H. Escherichia coli harboring Shiga toxin 2 gene variants: frequency and association with clinical symptoms. J Infect Dis. 2002;185:74-84.

39. Iyoda S, Manning SD, Seto K, Kimata K, Isobe J, Etoh Y, Ichihara S, Migita Y, Ogata K, Honda M, et al. Phylogenetic clades 6 and 8 of enterohemorrhagic Escherichia coli 0157:H7 with particular stx subtypes are more frequently found in isolates from hemolytic uremic syndrome patients than from asymptomatic carriers. Open Forum Infect Dis. 2014;1:ofu061.

40. Serra-Moreno R, Jofre J, Muniesa M. Insertion site occupancy by stx bacteriophages depends on the locus availability of the host strain chromosome. J Bacteriol. 2007;189:6645-54.

41. Besser TE, Shaikh N, Holt NJ, Tarr PI, Konkel ME, Malik-Kale P, Walsh CW, Whittam TS, Bono JL. Greater diversity of Shiga toxin-encoding bacteriophage insertion sites among Escherichia coli 157:H7 isolates from cattle than in those from humans. App Environ Microbiol. 2007:73:671-9.

42. Martinez-Castillo A, Quirós P, Navarro F, Miró E, Muniesa M. Shiga toxin 2encoding bacteriophages in human fecal samples from healthy individuals. Appl Environ Microbiol. 2013;79:4862-8

43. Baker J, Limberger R, Schneider SJ, Campbell A. Recombination and modular exchange in the genesis of new lambdoid phages. New Biol. 1991; 3:297-308.

44. Muylkens B, Farnir F, Meurens F, Schynts F, Vanderplasschen A, Georges M, Thiry E. Co-infection with two closely related alpha herpes viruses results in a highly diversified recombination mosaic displaying negative genetic interference. J Virol. 2009:83:3127-37.

45. van der Walt E, Rybicki EP, Varsani A, Polston JE, Billharz R, Donaldson L, Monjane AL, Martin D. Rapid host adaptation by extensive recombination. J Gen Virol. 2009:90:734-46.

46. Strauch E, Lurz R, Beutin L. Characterization of a Shiga toxin-encoding temperate bacteriophage of Shigella sonnei. Infect Immun. 2001;69:7588-95.

47. Gray MD, Lacher DW, Leonard SR, Abbott J, Zhao S, Lampel KA, Prothery E, Gouali M, Weill FX, Maurelli AT. Prevalence of Shiga toxin-producing Shigella species isolated from French travellers returning from the Caribbean: an emerging pathogen with international implications. Clin Microbiol Infect. 2015;21:765.e9-14

48. Tóth I, Sváb D, Bálint B, Brown-Jaque M, Maróti G. Comparative analysis of the Shiga toxin converting bacteriophage first detected in Shigella sonnei. Infect Genet Evol. 2016:37:150-7.

49. Ud-Din AIMS, Wahid SUH, Latif HA, Shahnaij M, Akter M, Azmi IJ, Hasan TN, Ahmed D, Hossain MA, Faruque ASG, Faruque SM, Talukder KA. Changing trends in the prevalence of Shigella species: emergence of multi-drug resistant Shigella sonnei biotype g in Bangladesh. PLoS One. 2013; https:// doi.org/10.1371/journal.pone.0082601.

50. Sváb D, Bálint B, Vásárhelyi B, Maróti G, Tóth I. Comparative genomic and phylogenetic analysis of a Shiga toxin producing Shigella sonnei (STSS) strain. Front Cell Infect Microbiol. 2017;7:229

51. Franki RIB, Fauquet CM, Knudson DL, Brown F. Classification and nomenclature of Viruses, 5th Report of the International Committee on Taxonomy of Viruses. Archives of Virology. Vienna: Springer; 1991. p. Suppl 2.

52. Brüssow H, Desiere F. Comparative phage genomics and the evolution of Siphoviridae: insights from dairy phages. Mol Microbiol. 2001;39:213-22.

53. Curtis FA, Reed P, Wilson LA, Bowers LY, Yeo RP, Sanderson JM, Walmsley AR, Sharples GJ. The C-terminus of the phage lambda Orf recombinase is involved in DNA binding. J Mol Recognit. 2011;24:333-40. 
54. De Paepe M, Hutinet G, Son O, Amarir-Bouhram J, Schbath S, Petit MA. Temperate phages acquire DNA from defective prophages by relaxed homologous recombination: the role of Rad52-like recombinases. PLoS Genet. 2014; https://doi.org/10.1371/journal.pgen.1004181.

55. Ogura Y, Ooka T, Iguchi A, Toh H, Asadulghani M, Oshima K, Kodama T, Abe H, Nakayama K, Kurokawa K, Tobe T, Hattori M, Hayashi T. Comparative genomics reveal the mechanism of the parallel evolution of $\mathrm{O} 157$ and nonO157 enterohemorrhagic Escherichia coli. Proc Natl Acad Sci U S A. 2009; 106:17939-44

56. Panis $G$, Franche N, Mejean V, Ansaldi M. Insights into the functions of a prophage recombination directionality factor. Viruses. 2012;4:2417-31.

57. Wang X, Kim Y, Ma Q, Hong SH, Pokusaeva K, Sturino JM, Wood TK. Cryptic prophages help bacteria cope with adverse environments. Nat Commun. 2010;1:147.

Ready to submit your research? Choose BMC and benefit from:

- fast, convenient online submission

- thorough peer review by experienced researchers in your field

- rapid publication on acceptance

- support for research data, including large and complex data types

- gold Open Access which fosters wider collaboration and increased citations

- maximum visibility for your research: over $100 \mathrm{M}$ website views per year

At $\mathrm{BMC}$, research is always in progress.

Learn more biomedcentral.com/submissions 